\title{
Impact Of Postgraduate Qualifications On The Career Progression of Middle Leaders in Schools
}

\author{
Ben Archer \\ James Cook University, Australia \\ ben.archer@my.jcu.edu.au
}

\author{
Received: 21 May 2021; Revised: 16 June 2021; Accepted: 22 July 2021 \\ DOI: http://dx.doi.org/10.37905/aksara.7.3.781-794.2021
}

\begin{abstract}
With a highly competitive higher education market in Australia, there is a significant push for professionals to obtain further qualifications. While much has been written on the progression to Principalship in schools, there is a paucity of writing on the progression into Middle Leadership. A survey of middle leaders in Australian schools indicate that the skills learned in postgraduate qualifications are highly valued by people entering Middle Leadership, however, no impact is recorded in relation to progression into further leadership roles. This research has the potential to influence the career decision making of school teachers and leaders, as well as influence the marketing of postgraduate qualifications by higher education providers.
\end{abstract}

\section{Keywords}

Middle leadership, schools, teacher careers, higher education, leadership skills

\section{INTRODUCTION}

Schools are naturally hierarchical organisations, with a school leader known as the Principal in charge of the overall direction and success of the institution. The success of the school often lands on the middle leadership of the school, who hold the responsibility for implementing the strategy set out by the executive leaders (Yukl, 2013, p. 162). People entering middle leadership need to possess an array of technical as well as personable skills to be successful. These skills help enable both the personal success of the middle leader and their team, but also help advance the school towards achieving their strategic goals. Effective leadership in a school is the core element in student achievement and outcomes (Australian Institute of Teaching and School Leadership, 2017). This has been supported by many others in recent times, where links between school leadership and school success have been made apparent (Carter, 2016; De Nobile, 2018; Harris, 2003). However, the process of moving from teacher to middle leader remains unclear. The career development of teachers remains an area of research focussed primarily on the Principal and other school executives. This is despite distributive leadership models becoming more commonplace in schools today (Hulpia et al., 2009). School hierarchy structures tend to divide subsets of students through year levels (based on age), and subject areas. The teachers who are placed in charge of these areas are usually assigned a role of middle leadership. Roles such as subject curriculum coordinator, pastoral care 
coordinator and advisors on teaching and learning are usually assigned middle leadership positions (Carter, 2016, p. 39). Middle leadership is directly answerable to a member of the executive team who has been assigned to a position that is directly supervisory to them. For example, a pastoral care coordinator would be directly answerable to a Deputy Principal for Student Welfare. These hierarchical structures allow for the leadership of the school to be distributed across areas of responsibility, and in theory allow for the smooth, efficient running of the school (Harris et al., 2019, p. 256). In reality, a tension exists for middle leaders, as they are torn between the directions provided to them by the executive leadership team and the expectations placed upon them by the team they are leading (Bennett et al., 2007, p. 456). Being able to navigate this tension successfully is the hallmark of a successful middle leader (Yukl, 2013, p. 392). This raises the question of skill development, and how leaders build and develop their skill. Postgraduate qualifications are often marketed as a key to career development (Daymon \& Durkin, 2013, p. 596). In many industries, completion of a postgraduate qualification can improve the promotional opportunities for an individual. Wakeling and Laurison highlight that a tension exists in the workforce; that as postgraduate degrees become more accessible, that their value is decreasing in industries where tertiary qualifications are a requirement for entry (2017, p. 551). Given the need for middle leaders in schools to have both technical and personable expertise, and the growth of opportunities for postgraduate study, there is a need to investigate the role of postgraduate qualifications in relation to middle leadership in schools.

\section{METHOD}

To test these hypotheses, quantitative research methods were deployed to survey middle leaders in schools in Australia. Surveys were distributed via social media into professional teacher groups on Facebook and LinkedIn. Respondents were filtered by the opening two questions, which asked teachers to state their existing role. If a respondent answered their current role as Executive Leadership or non-leadership roles, they were filtered from the survey. Question 2 asked respondents to identify what school sector they were employed in, with choices of Government, Catholic, Independent, and International. Question 3 asked respondents to select the country they were working in as the potential existed that international teachers could respond. Question 4 required respondents to select the year levels taught by their school, with questions $5 \& 6$ asking about gender and age respectively. Question 7 asked respondents whether they have completed a postgraduate qualification, with a yes/no choice selection. If respondents selected No, they were taken to Question 12 and excluded from Questions 8-11. Question 8 asked respondents to check a box outlining the level of their postgraduate qualification, between a Certificate, Diploma, Masters or Higher Degree by Research. Question 9 asked respondents to state the full title of their degree, including the level of qualification. Question 10 asked respondents whether they obtained their qualification prior to being promotion. If respondents answered no, they were presented with Question $11 \mathrm{~b}$ only. If respondents answered yes, they were presented with Question 11a and Question 11b.

Question 11 was broken into two sections and is herein referred to as Question 11a and Question 11b. The question required participants to use a 1-5 Likert scale to answer the following:11a: Your postgraduate qualification was an influence in your ability to obtain your current position 
11b: Your postgraduate qualification has an influence on the likelihood of being promoted again

Question 12 asked respondents to state whether they had intentions on undertaking further postgraduate study, with a Yes/No response.

To test the hypothesis that postgraduate qualifications are not a causal factor for the promotion of teachers to middle leadership, a median frequency test was conducted on Question 11a. Through conducting a median frequency test, it can be determined whether the majority of respondents believe their postgraduate qualifications were an influence on their promotion to middle leadership. To test the hypothesis that teachers perceive postgraduate qualifications as a causal factor for promotions in schools, a median frequency test was conducted on Question 11b. Through conducting a median frequency test, it can be determined whether the majority of respondents believe that a postgraduate qualification is an influence on promotional positions being awarded. To test the hypothesis that teachers perceive postgraduate qualifications as an influence on their ability to gain promotions from middle leadership, a chi-square test of independence was conducted on Questions 7 and 12. If the level of significance was 0.05 or greater, then this would indicate support for $\mathrm{H}_{2}$. This would highlight that teachers do not perceive postgraduate qualifications as a causal factor for promotional opportunities beyond middle leadership.

\section{RESULTS}

There were 81 respondents to the survey, out of which 48 were currently employed in middle leadership roles within Australian schools $(n=48) .33$ respondents were excluded from the survey as they did not meet the criteria of working in middle leadership in a school environment. Answers to question 2 indicate that most respondents were employed in the Independent school sector $(77.08 \%)$ with Government sector employees (12.5\%) and Catholic sector employees (10.42\%) also represented (Figure A). No responses were recorded from employees in international schoolcontexts.

Figure A: Responses to Question 2 "What type of school do you current work in?"

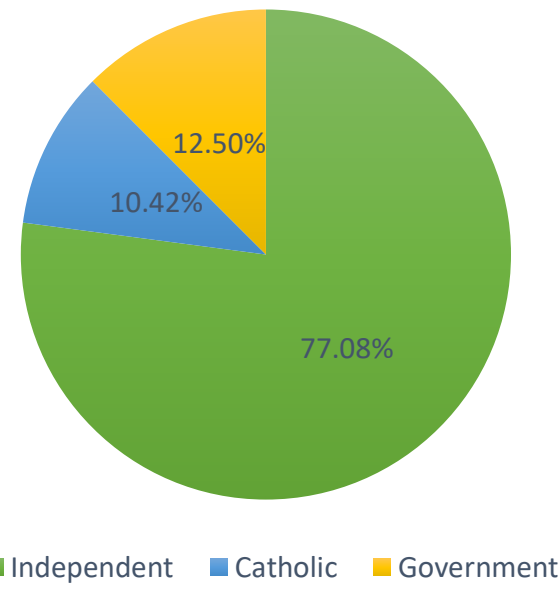


Question 3 asked respondents to identify which country they currently worked in. Despite the survey being shared predominantly in Australian teaching groups, the potential exists that international school respondents could have participated. Despite this, $100 \%$ of respondents answered that they were employed in Australia. Question 4 asked respondents which year levels their school teaches. The responses fell into two categories - Kindergarten to Year 12 (54\%) and Secondary [7-12] (46\%). The potential exists that all respondents to the survey work in secondary contexts. However, this cannot be confirmed based on the responses to the question. Given that secondary schools tend to require more middle leadership roles than primary schools, the proportion of responses to this question is not surprising.

Figure B: Responses to Question 4 "What year levels does your school teach?"

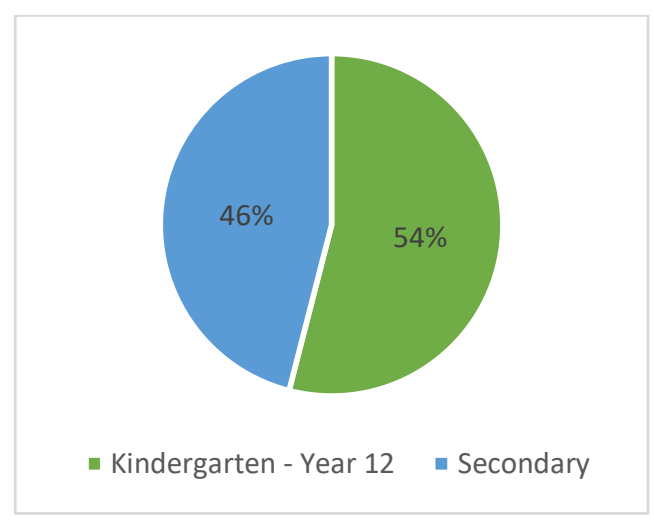

Question 5 asked participants to identify their gender, with male, female, nonbinary and non-disclosure as options. 15 respondents indicated they were male (31\%), 33 respondents indicated that they were female $(69 \%)$. This is akin to the proportion of male and female teachers in Australian schools (Australian Bureau of Statistics, 2020). Figure $\mathrm{C}$ provides a comparison of gender ratio between survey respondents and current teaching staff statistics taken from the Australian Bureau of Statistics 2019 Schools release.

Figure C: Responses to Question 5: "What is your gender" comparison with current make-up of Australian school teaching staff (Australian Bureau of Statistics, 2020)

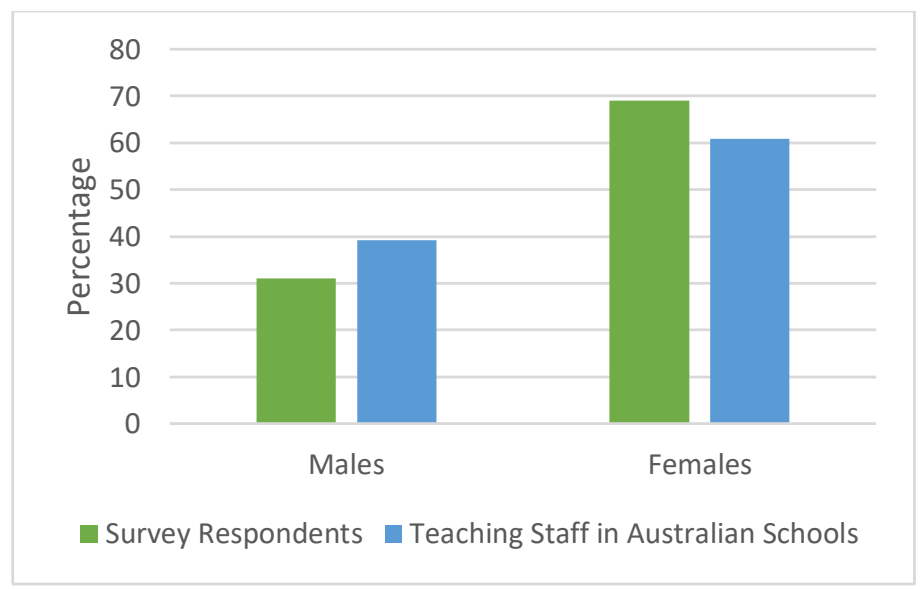

784 AKSARA: Jurnal Ilmu Pendidikan Nonformal 
Question 6 asked respondents to declare their age. This was the final demographic question; it was included to determine whether a correlation could be established between age and postgraduate qualifications. However, due to the sample size any analysis would not have delivered a reliably significant result. Most respondents indicated that they were aged $35-44(33 \%)$, with $45-54$ being the second most significant age bracket (27\%). No respondents indicated that they were aged $18-24$. Figure D provides an overview of the range of responses to Question 6.

Figure D: Responses to Question 6: "What is your age?"

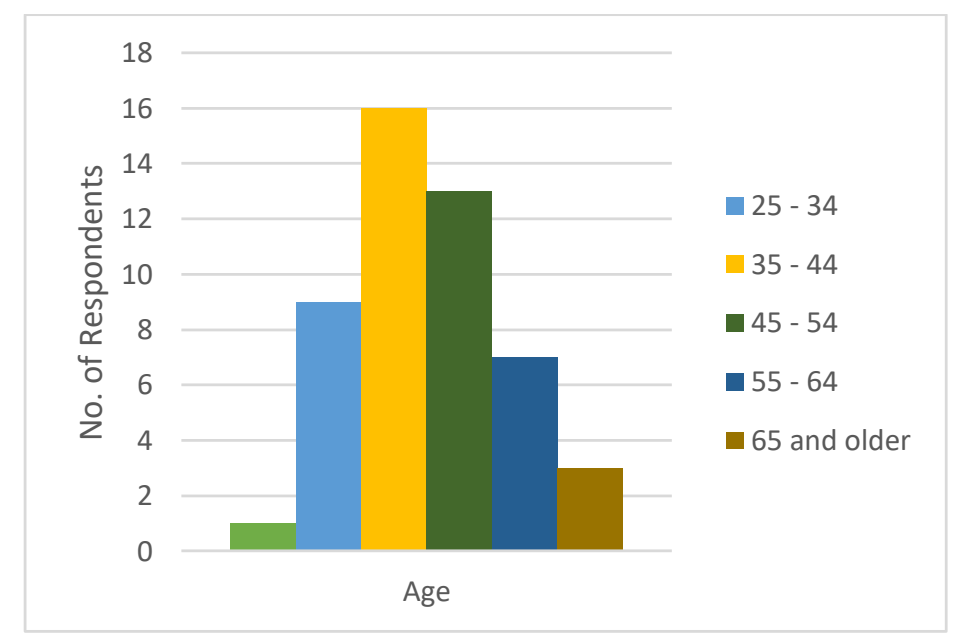

Question 7 asked respondents to state whether they had obtained a postgraduate qualification. This was a recorded as a yes/no response, with responses coded as 1 for yes, and 0 for no. If a respondent answered 'yes', they moved to Question 8 and completed all remaining questions. If a respondent answered 'no', moved straight to to Question 11b. 26 respondents answered that they had completed a postgraduate qualification, with 22 reporting that they had not completed a postgraduate qualification. Figure E provides an overview of the two answers as a percentage of respondents. The answers to Question 7 formed the independent variable for the statistical analysis of the data collected from the survey.

Figure E: Responses to Question 7 "Have you completed a postgraduate qualification?"

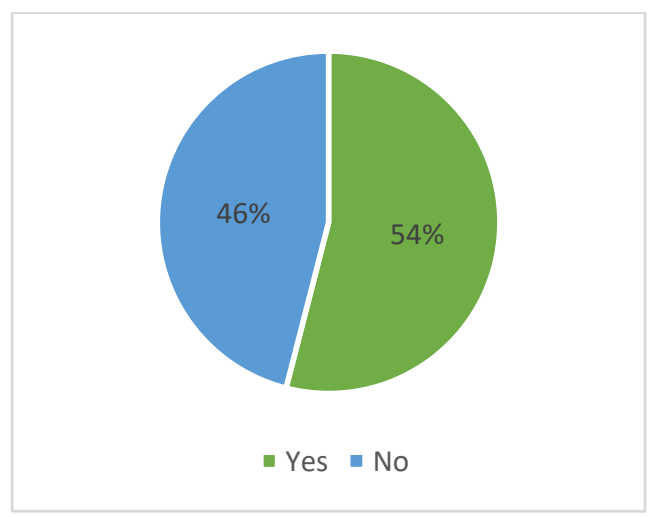


Question 8 asked respondents to name the level of qualification completed. These levels were drawn from the Australian Qualification Framework at level 8 and above, with Graduate Certificate, Graduate Diploma, Masters by Coursework and Higher Degree by Research as the options available (Department of Education, Skills and Employment, 2015). Respondents were able to tick all responses that applied due to recognition that a person may hold multiple postgraduate qualifications. Figure F provides the range of responses as a percentage. No statistical analysis was completed with regards to Question 8 , as the sample size was not large enough to provide a reliably significant result.

\section{Figure F: Responses to Question 8 "What level qualification did you complete?"}

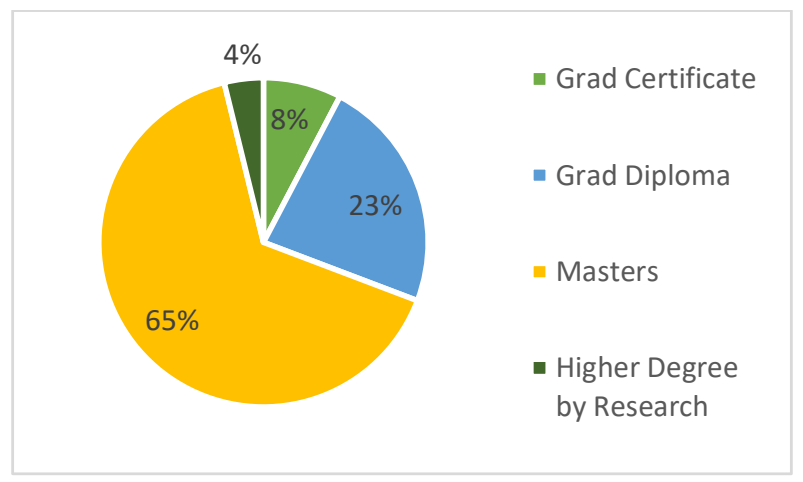

Question 9 asked respondents to list each of the postgraduate qualifications they had completed. The majority of respondents completed a Master of Education or an education-related qualification. The remainder of responses included teaching-area specific qualifications that were content-focussed, and not necessarily directly related to education. Table A provides a categorised list of qualifications by discipline and by level. The categorisation identifies the difference between qualifications obtained in the education discipline and teaching-area specific disciplines.

Table A: Categorised responses to Question 9: "What is the name of your qualification (e.g. Postgraduate Certificate of Education)? If you have multiple, please include a semicolon (;) between them."

\begin{tabular}{|l|l|l|}
\hline Level of Qualification & Discipline & Number of Respondents \\
\hline Graduate Certificate & Education & 2 \\
\hline & Career Development & 1 \\
\hline Graduate Diploma & Education & 8 \\
\hline Masters by Coursework & Education & 14 \\
\hline & Arts & 2 \\
\hline & Science & 2 \\
\hline
\end{tabular}


Question 10 asked respondents to state whether they had completed their qualification prior to moving into middle leadership. Responses were recorded as a yes/no answer, with 1 coded for 'yes' responses, and 0 recorded for 'no' responses. 17 of the respondents who had completed a postgraduate qualification indicated that they had achieved the qualification prior to moving into middle leadership. Figure $\mathrm{G}$ provides a percentage overview of responses.

Figure G: Responses to Question 10: "Did you complete this qualification prior to commencing your leadership position?"

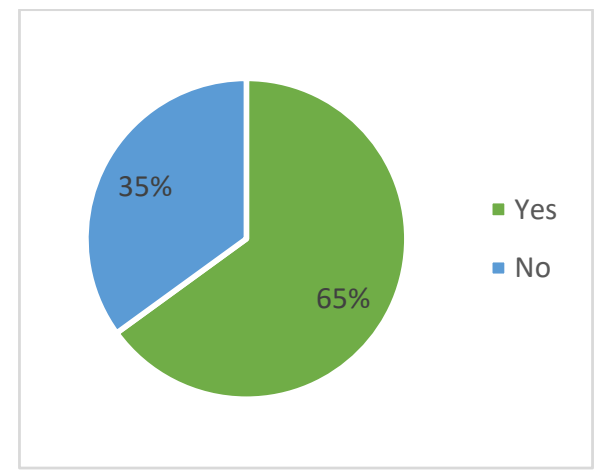

Question 11 required respondents to use a $1-5$ Likert scale to respond to two statements. These are herein referred to $11 \mathrm{a}$ and $11 \mathrm{~b}$. The questions and responses are detailed below in Table B. Question 11b received more responses than 11a, as respondents who answered 'no' to question 7 were directed straight to $11 \mathrm{~b}$. Data from questions $11 \mathrm{a}$ and $11 \mathrm{~b}$ were used to test the hypothesis that postgraduate qualifications have not been a causal factor for the promotion of teachers to middle leadership.

Table B: Responses to Questions 11a and 11b

\begin{tabular}{|l|l|l|l|l|l|}
\hline & $\begin{array}{l}\text { Not at } \\
\text { all (1) }\end{array}$ & $\begin{array}{l}\text { Minimal } \\
\text { influence } \\
(2)\end{array}$ & $\begin{array}{l}\text { Some } \\
\text { influence } \\
(3)\end{array}$ & $\begin{array}{l}\text { Somewhat } \\
\text { influential } \\
(4)\end{array}$ & $\begin{array}{l}\text { Highly } \\
\text { influential } \\
(5)\end{array}$ \\
\hline $\begin{array}{l}\text { Your postgraduate } \\
\text { qualification was an } \\
\text { influence in your } \\
\text { ability to obtain your } \\
\text { current position }\end{array}$ & 5 & 1 & 2 & 3 & 6 \\
\hline $\begin{array}{l}\text { Your postgraduate } \\
\text { qualification has an } \\
\text { influence on the } \\
\text { likelihood of being } \\
\text { promoted further }\end{array}$ & 8 & 7 & 5 & 2 & 4 \\
\hline
\end{tabular}

A median frequency test was used on Question 11a to test $\mathrm{H}_{0}$, which states: Postgraduate qualifications have not been a causal factor for the promotion of teachers to middle leadership. A result above 2.0 would cause a rejection of this hypothesis and 
provide support for $\mathrm{H}_{1}$ which states: Postgraduate qualifications are a causal factor for the promotion of teachers to middle leadership. Eleven respondents stated that their postgraduate qualification had at least some influence on their ability to be promoted into middle leadership. Figure $\mathrm{H}$ details the median frequency test that was applied to Question 11a, which indicates a median response of 3.5.

Figure H: Median frequency test applied to Question 11a.

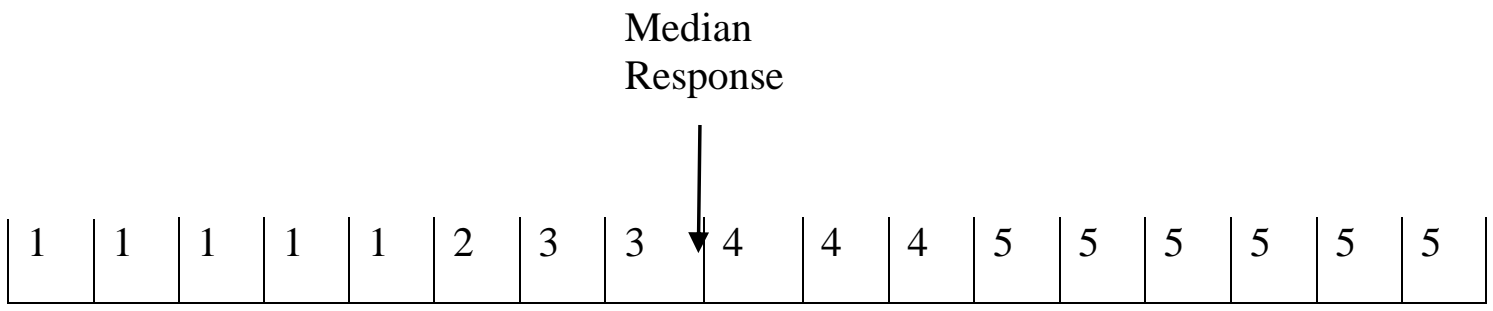

Given that the median frequency for Question 11a was 3.5, the null hypothesis of $\mathrm{H}_{0}$ must be rejected. If $\mathrm{H}_{0}$ is rejected, then there is adequate support for $\mathrm{H}_{1}$ : Postgraduate qualifications are a causal factor for the promotion of teachers to middle leadership.

A median frequency test was conducted on Question 11b, which asked respondents to provide an answer on a 1-5 Likert scale to the statement: Your postgraduate qualification has an influence on the likelihood of being promoted further.

As the median response was 2.0 , there is data to support $\mathrm{H}_{4}$, indicating that teachers do not perceive postgraduate qualifications as an important factor for their future promotion opportunities. Figure I details the median frequency test undertaken.

Figure I: Median frequency test for Question 11b

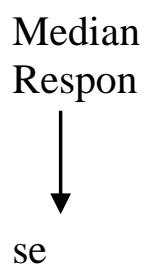

\begin{tabular}{|l|l|l|l|l|l|l|l|l|l|l|l|l|l|l|l|l|l|l|l|l|l|l|l|l|l|l|}
\hline 1 & 1 & 1 & 1 & 1 & 1 & 1 & 1 & 2 & 2 & 2 & 2 & 2 & 2 & 2 & 3 & 3 & 3 & 3 & 3 & 4 & 4 & 5 & 5 & 5 & 5 & 5 \\
\hline
\end{tabular}

Question 12 required respondents to declare whether they intended on completing postgraduate qualifications in the future to enhance their career. Respondents chose their response on a Yes/No basis. All respondents in the survey were asked this question. Figure J summarises the responses, with 25 respondents answering "Yes", representing $52 \%$ of the sample size.

Figure J: Responses to Question 12: Do you intend on undertaking a postgraduate qualification in the future to enhance your career? 


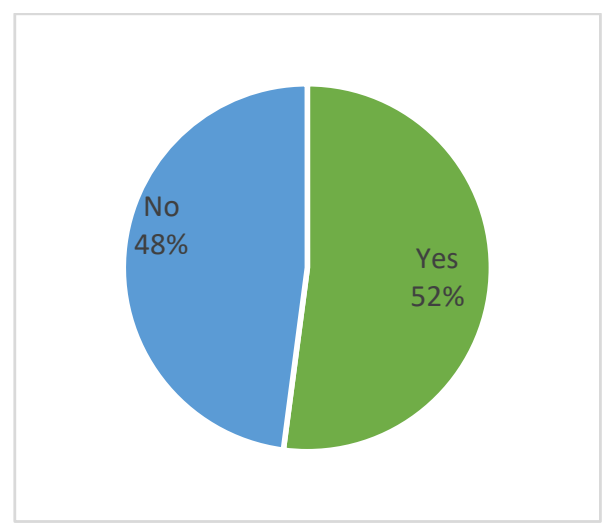

To test $\mathrm{H}_{2}$ whether teachers do not perceive postgraduate qualifications as a causal factor for promotion from middle leadership, a chi-square test for independence was conducted on the answers for Question 7 and Question 12. Answers "yes" were coded as 1 , and answers "no" were coded as 0 . If independence between the two sets of responses was determined, then it would indicate that teachers do not perceive postgraduate qualifications as a causal factor for promotion from middle leadership. The level of significance hypothesised was 0.05 or greater to highlight independence, and subsequently support the hypothesis that teachers do not perceive postgraduate qualifications as a causal factor for promotion from middle leadership. Table $\mathrm{C}$ details the chi-square test for independence that was conducted.

Table C: Chi-Square Test for Independence Performed on Questions 7 and 12.

\begin{tabular}{|c|c|c|c|c|c|}
\hline \multicolumn{4}{|c|}{ Observed Frequencies } & \multirow{2}{*}{\multicolumn{2}{|c|}{ Results }} \\
\hline & Question 7 & Question 12 & Total & & \\
\hline Yes & 26 & 25 & 51 & $\begin{array}{l}\text { Critical } \\
\text { Value }\end{array}$ & 3.84145882 \\
\hline No & 22 & 23 & 45 & $\begin{array}{l}\text { Chi- } \\
\text { Square } \\
\text { Test } \\
\text { Statistic }\end{array}$ & 0.04183007 \\
\hline Total & 48 & 48 & 96 & $p$-Value & 0.83794404 \\
\hline
\end{tabular}

As the $\mathrm{p}$-value is greater than 0.05 , this indicates that $\mathrm{H}_{2}$ is supported; that teachers do not perceive postgraduate qualifications as a causal factor for promotion from middle leadership. Therefore, as $\mathrm{H}_{2}$ is supported, $\mathrm{H}_{3}$ must be rejected.

\section{DISCUSSION}

Three hypotheses were supported through this survey.

$\mathrm{H}_{1}$ : Postgraduate qualifications are a causal factor for the promotion of teachers to middle leadership.

$\mathrm{H}_{2}$ : Teachers do not perceive postgraduate qualifications as a causal factor for promotion from middle leadership 
$\mathrm{H}_{4}$ : Teachers do not perceive postgraduate qualifications as a causal factor for promotions in schools

The contrast between $\mathrm{H}_{1}$ and $\mathrm{H}_{4}$ is interesting. While the evidence supports the notion that postgraduate qualifications are a causal factor for the promotion of teachers to middle leadership, there is a perception that the reverse is the case. This indicates that Wakeling's (2005) theory on the role of postgraduate qualifications in industries that few hold postgraduate qualifications is not applicable to the school-based education industry. It is interesting that a perception exists within schools that postgraduate qualifications are not required for career progression. Future research could investigate the role that postgraduate qualifications have had on the career progression of teachers into executive leadership positions. The impact that the support of $\mathrm{H}_{2}$ has Daymon \& Durkin's (2013) theory that postgraduate qualifications are marketed towards career development needs to be considered in relation to schools. While many teachers reported in Question 12 that they intended on undertaking postgraduate qualifications for their own career development, they also perceived this as not a causal factor for promotion. The inference could be that postgraduate qualifications are sought after by teachers in order to enhance their skill development; which could then be a causal factor in promotion from middle leadership. The role of Daymon \& Durkin's hypothesis relating to the marketing of postgraduate qualifications has an impact on the way in which tertiary institutions approach the education sector. The potential exists that future marketing activities that focus on the skills developed during a postgraduate course could attract more teachers into the course, as opposed to a focus on career development and promotion. Future research should lend itself towards having a larger sample size, with greater representation from primary schools being an area of focus. If the existing hypotheses were supported, this would have implications for the future marketing of postgraduate courses for teachers. Potentially, research could attempt to compare the experiences of teachers in different countries. This would lend greater support to Daymon \& Durkin's theory, as a portion of their research compared the experiences of postgraduate course coordinators in the United Kingdom with Australia. Given that research from Wakeling and Laurison (2017) was based on data from the United Kingdom, there is significant space for a cross-country comparison.

\section{CONCLUSION}

Through the investigation of the role of postgraduate qualifications on the career development of middle leaders in schools, there is evidence to show a difference in perceptions and actuality. While postgraduate qualifications are marketed as career development mechanisms (Daymon \& Durkin, 2013), the actuality is that the skills learned in the qualifications are potentially more important to teachers than the qualifications themselves. Arguably, the skills learned in the postgraduate qualifications allow middle leaders to better navigate the tension between the directions of the executive team, and the expectations of the team they are leading. This has implications for tertiary institutions who are offering postgraduate qualifications in education. There is a need to have greater focus on skills development within the qualifications as opposed to a focus on career development. As teachers do not perceive postgraduate qualifications as a causal factor for promotion either to middle leadership, or out of middle leadership, the potential exists that future qualifications will need to have a focus on the applicability of 
the content learned. Subsequently, while postgraduate qualifications in and of themselves will not have a direct bearing on promotion out of middle leadership, teachers will need to exhibit the skills learned in the workplace in order to gain further promotions. This could be a focus of future in-school mentoring programs for leadership development. Wakeling's (2005) theory that postgraduate qualifications are most valuable in industries where few people hold postgraduate qualifications is also drawn into question by this research. The majority of respondents held postgraduate qualifications and that postgraduate qualifications were shown to be a causal factor in the achievement of promotion to middle leadership. This leads to the question of whether postgraduate qualifications are a causal factor for promotion to a certain point, and then they cease to be important. Overall, the research demonstrated that postgraduate qualifications do have a role to play in the career development of teachers. Those seeking middle management positions should seek to build and develop their skills in order to move to the next stage in their career. However, the skills developed and implemented appear to have more weight in moving out of middle leadership as opposed to simply holding the qualifications themselves. Institutions who are offering postgraduate qualifications for teachers have the potential to adjust their focus to skill development, as opposed to career development. This will have a strong impact on the career development of teachers, as well as help contribute to student outcomes and school success.

\section{REFERENCE}

Australian Bureau of Statistics. (2020, June 2). Schools, 2019. https://www.abs.gov.au/statistics/people/education/schools/latest-release

Australian Institute of Teaching and School Leadership. (2017). Lead \& develop. Lead and Develop. https://www.aitsl.edu.au/lead-develop

Bennett, N., Woods, P., Wise, C., \& Newton, W. (2007). Understandings of middle leadership in secondary schools: A review of empirical research. School Leadership \& Management, 27(5), 453-470. https://doi.org/10.1080/13632430701606137

Carter, A. (2016). Empowering middle leaders - Trends in school leadership research on the principal's impact on school effectiveness. Australian Educational Leader, 38(1), 37-41.

Coen, D., \& Vannoni, M. (2020). Where Are the Revolving Doors in Brussels? Sector Switching and Career Progression in EU Business-Government Affairs. The American Review of Public Administration, 50(1), 3-17. https://doi.org/10.1177/0275074019861360

Daymon, C., \& Durkin, K. (2013). The impact of marketisation on postgraduate career preparedness in a high skills economy. Studies in Higher Education, 38(4), 595612. https://doi.org/10.1080/03075079.2011.590896

De Nobile, J. (2018). Towards a theoretical model of middle leadership in schools. School $\begin{array}{llll}\text { Leadership \& } \quad \text { Management, } & \text { 38(4), 395-416. }\end{array}$ https://doi.org/10.1080/13632434.2017.1411902

Department of Education, Skills and Employment. (2015, February 6). AQF qualifications. Australian Skills Qualification Framework. https://www.aqf.edu.au/aqf-qualifications

Galdames, S., \& Gonzalez, A. (2016). The relationship between leadership preparation and the level of teachers' interest in assuming a principalship in Chile. School 
Leadership \& Management, 36(4), 435-451. https://doi.org/10.1080/13632434.2016.1209178

Giles, M., Ski, C., \& Vrdoljak, D. (2009). Career Pathways of Science, Engineering and Technology Research Postgraduates. Australian Journal of Education, 53(1), 6986. https://doi.org/10.1177/000494410905300106

Gurmu, T. G. (2020). Primary school principals in Ethiopia: Selection and preparation. Educational Management Administration \& Leadership, 48(4), 651-681. https://doi.org/10.1177/1741143219836673

Harris, A. (2003). Distributed Leadership in Schools: Leading or misleading? Management in Education, 16(5), 10-13. https://doi.org/10.1177/089202060301600504

Harris, A., Jones, M., Ismail, N., \& Nguyen, D. (2019). Middle leaders and middle leadership in schools: Exploring the knowledge base (2003-2017). School Leadership \& Management, 39(3-4), 255-277. https://doi.org/10.1080/13632434.2019.1578738

Hulpia, H., Devos, G., \& Rosseel, Y. (2009). Development and Validation of Scores on the Distributed Leadership Inventory. Educational and Psychological Measurement, 69(6), 1013-1034. https://doi.org/10.1177/0013164409344490

Jacob, M., \& Klein, M. (2019). Social origin, field of study and graduates' career progression: Does social inequality vary across fields? The British Journal of Sociology, 70(5), 1850-1873. https://doi.org/10.1111/1468-4446.12696

Javadi, V., Bush, T., \& Ng, A. (2017). Middle leadership in international schools: Evidence from Malaysia. School Leadership \& Management, 37(5), 476-499. https://doi.org/10.1080/13632434.2017.1366439

Lin Choi, P. (2013). Gender identities and career aspirations of middle leaders: Cases in Hong Kong secondary schools. International Journal of Educational Management, 27(1), 38-53. https://doi.org/10.1108/09513541311289819

Miller, P. (2016). 'White sanction', institutional, group and individual interaction in the promotion and progression of black and minority ethnic academics and teachers in England. Power and Education, 8(3), 205-221. https://doi.org/10.1177/1757743816672880

Moos, L., Krejsler, J., Kasper Kofod, K., \& Brandt Jensen, B. (2005). Successful school principalship in Danish schools. Journal of Educational Administration, 43(6), 563-572. https://doi.org/10.1108/09578230510625665

Neary, S. (2014). Reclaiming professional identity through postgraduate professional development: Careers practitioners reclaiming their professional selves. British Journal of Guidance \& Counselling, 42(2), 199-210. https://doi.org/10.1080/03069885.2013.869790

Notman, R. (2012). Intrapersonal factors in New Zealand school leadership success. International Journal of Educational Management, 26(5), 470-479. https://doi.org/10.1108/09513541211240264

Pashiardis, P., \& Orphanou, S. (1999). An insight into elementary principalship in Cyprus: The teachers' perspective. International Journal of Educational Management, 13(5), 241-251. https://doi.org/10.1108/09513549910286594

Scanlan, G. M., Cleland, J., Stirling, S. A., Walker, K., \& Johnston, P. (2019). Does initial postgraduate career intention and social demographics predict perceived career 
behaviour? A national cross-sectional survey of UK postgraduate doctors. BMJ Open, 9(8), e026444. https://doi.org/10.1136/bmjopen-2018-026444

Syed, S., \& Duncan, A. (2019). Role Emerging Placements: Skills Development, Postgraduate Employment, and Career Pathways. Open Journal of Occupational Therapy, 7(1), 1-18. https://doi.org/10.15453/2168-6408.1489

Thody, A., Papanaoum, Z., Johansson, O., \& Pashiardis, P. (2007). School principal preparation in Europe. International Journal of Educational Management, 21(1), 37-53. https://doi.org/10.1108/09513540710716812

Wakeling, P. (2005). La noblesse d'état anglaise? Social Class and Progression to Postgraduate Study. British Journal of Sociology of Education, 26(4), 505-522. http://www.jstor.org/stable/30036087

Wakeling, P., \& Laurison, D. (2017). Are postgraduate qualifications the 'new frontier of social mobility'? The British Journal of Sociology, 68(3), 533-555. https://doi.org/10.1111/1468-4446.12277

Walker, A., \& Qian, H. (2015). Review of research on school principal leadership in mainland China, 1998-2013: Continuity and change. Journal of Educational Administration, 53(4), 467-491. https://doi.org/10.1108/JEA-05-2014-0063

Yukl, G. (2013). Leadership in Organisations (8th ed., Vol. 1). Pearson Education Ltd. 
AKSARA: Jurnal Ilmu Pendidikan Nonformal

P-ISSN 2407-8018 E-ISSN 2721-7310 DOI prefix 10.37905

Volume 07, (03) September 2021

http://ejurnal.pps.ung.ac.id/index.php/Aksara 